Hydroécol. Appl. (1992) Tome 4 Vol 1, pp. 1-11

\title{
Power generation on the british coast: thirty years of marine biological research
}

\section{Andrew W.H. Turnpenny and Jack Coughlan}

Fawley aquatic research laboratories Ltd, Marine and Freshwater Biology Unit, Fawley, Southampton, Hampshire, SO4 1TW, UK

\begin{abstract}
Industry-based marine biologists have investigated a wide range of issues relating to coastal power generation since its expansion in Britain in the 1950s. Early fears of wide-scale ecological damage arising from discharge of heated effluent proved to be unfounded. The removals of fish and other natant organisms by cooling water abstraction have also been shown to be of no consequence, either ecologically or to the fishing industry. Biofouling of cooling systems, once a crippling problem for the industry, has been largely brought under control by low-level chlorine application. Marine dumping of coal ash (PFA) is due to cease shortly, and novel opportunities for use of solid by-products for marine habitat enhancement are being investigated. Studies in all areas continue, so that the industry can pursue improving environmental practices.
\end{abstract}

Key words. - Marine biology - Power generation - Heated effluent - Removals of organisms. Chlorine application - Dumping of ash - Marine habitat enhancement.

Résumé. - Les investigations des biologistes marins quant à l'impact des centrales électriques remontent aux années 1950 en Grande-Bretagne. Les premières craintes de dommages écologiques à grande échelle résultant du rejet d'effluents échauffés se sont avérées infondées. II a aussi été montré que les disparitions de poissons et autres organismes aquatiques par aspiration avec les eaux de refroidissement n'avaient pas de conséquence écologique ni d'impact sur l'industrie de la pêche. L'encrassement biologique des systèmes de refroidissement, qui était un problème majeur pour l'industrie, a été réglé par l'utilisation de chlore à faibles doses. Les rejets en mer de cendres de charbons (PFA) vont cesser très prochainement, et de nouvelles opportunités pour l'utilisation de produits de recyclages solides pour la valorisation de l'habitat marin sont à l'étude. Les recherches se poursuivent dans tous les domaines, prouvant la motivation des industriels en matière de protection de l'Environnement.

Mots-clés. - Biologie marine - Centrales électriques - Rejets thermiques - Entraînements des organismes - Chloration - Emissions de cendre - Valorisation de l'habitat marin. 


\section{INTRODUCTION}

Today, of 80 GWe installed electricity generating capacity operated by the main producers in Britain, some $46 \%$ is sited on open coasts or estuaries (fig. 1).

Until the 1950s, the majority of Britain's thermal generating capacity was located inland, in and around urban centres, using river water for plant cooling purposes. The shift towards es- tuarine and coastal generation was prompted by a number of factors. First, the 1956 Clean Air Act had effectively ruled out the redevelopment of urban sites. Second, the increasing size of generating units necessitated larger sites with substantial volumes of cooling water, neither of which were available in urban areas. Third, a growing energy gap ushered in the first civil nuclear programme and early nuclear stations were built away from population centres. Finally, expansion of oil refining capacity made available
1. Hoy $\mathrm{h} a \mathrm{~m}$

2. Wy 1 a

3. Pombrok

4. Aberihaw

5. Uakmouih

6. Oldbury

7. Berkel ey

8. HInkloy Polnt

9. Fawl oy

10. Dungones:

11. IsI. of Gral n

12. KInganorih

13. LIt ll brook

14. W. Thurrock

15. TII bury

16. Bradwoll

17. Sizewol I

18. Herllepool

19. B। yi h

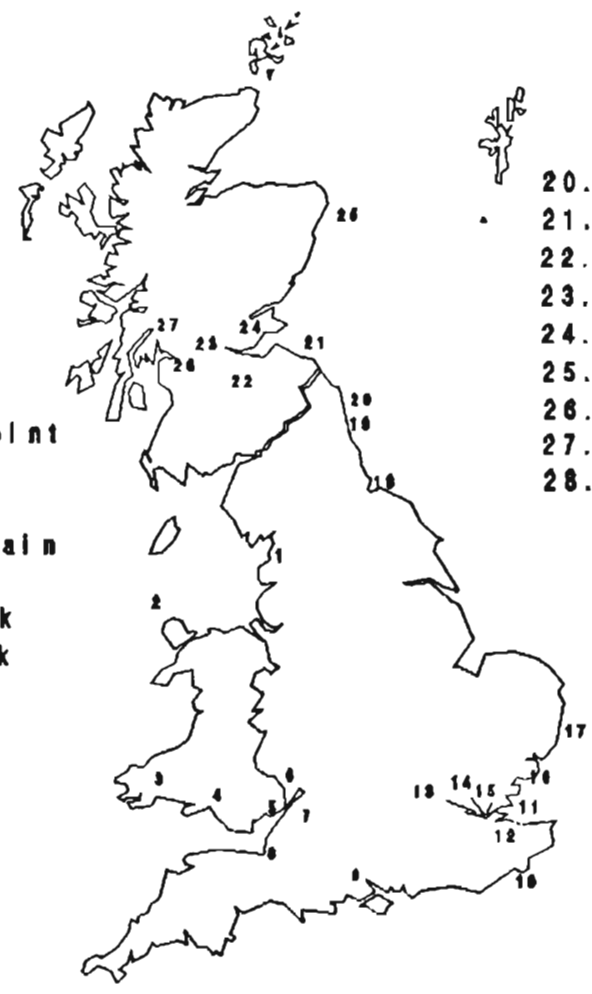

Fig. 1. - Coastal and Estuarine Power Stations in Britain. 
large volumes of heavy fuel oil at low cost; major new stations were sited alongside the new refineries at Pembroke, Fawley and in the Thames Estuary. These stations could take advantage of large available areas of low-lying, level land of little monetary value.

The need for marine biological studies was recognised at an early stage. Proposals to build the first two nuclear power stations at Berkeley and Bradwell sparked immediate opposition which, at Bradwell, led to a four day Public Inquiry. There were deeply held views about the possible effects of the new station on the local fishing industry, an area at that time holding the most productive oyster (ustrea edulis) grounds in the country. After giving consent for the Bradwell station, the Inspector recommended that biological studies should be undertaken to allay the fears of the fishing industry. This gave rise to the team of marine biologists, formerly within the CEGB and subsequently part of the Research and Technology Department of National Power, based at Fawley (Hampshire).

Much has been written about the marine biological consequences of power generation. In this paper we review some of the key issues from an historical perspective leading to the current position.

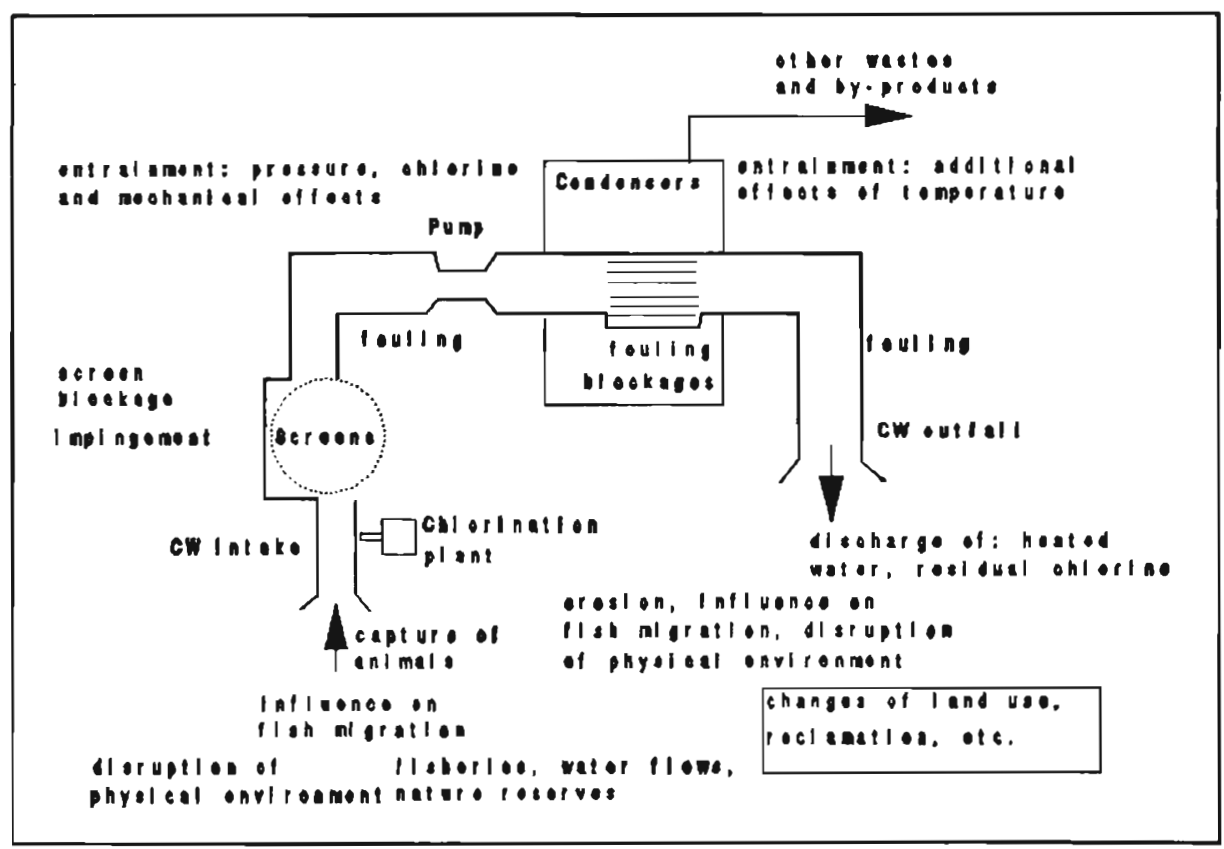

Fig. 2. - Summary of Potential Interactions between Thermal Power Stations and the Marine Environment. 
INTERACTIONS BETWEEN

THERMAL POWER STATIONS AND THE MARINE ENVIRONMENT

The principal interactions between an estuarine or coastally-sited power station and the marine environment are shown in Figure 2. These can be placed in three broad categories:

1. effects arising from engineering construction and site occupation;

2. effects arising from solid and liquid waste disposal; and

3. consequences of cooling water (CW) system operation.

The last of these requires some further explanation. A direct-cooled $1000 \mathrm{MWe}$ conventional power station requires 30 cubic metres of cooling water each second. For a Pressurised Water Reactor this rises to more than $40 \mathrm{~m}^{3} \mathrm{~s}^{-1}$. As this water enters the intake, it draws with it any suspended weed and debris, as well as fish and other aquatic animals that cannot escape the flow. To prevent blockage of the heat exchangers this material is removed by small-mesh $(8-10 \mathrm{~mm})$ screens and is normally rejected to trash bins. Smaller organisms penetrate the screens and pass through the CW system where they are subjected to stresses including mechanical shock, abrupt temperature changes and, when in use, exposure to biocides such as chlorine. Beyond the point of discharge, a variety of generic and site-specific issues have been raised by objectors. These range from thermal effects on the physiology and behaviour of organisms and establishment or elimination of species, to non-thermal effects arising from biocide discharge, modification of water currents and deoxygenation of the sea bed and water column.

\section{EFFECTS OF THERMAL DISCHARGES}

By 1950 thermal discharges were firmly established as an important environmental issue on inland sites. It was not surprising, therefore, that thermal stress in estuarine and marine ecosystems was quickly taken up by objectors, particularly commercial fishermen who stood to lose their livelihood if the catastrophes predicted by 'experts' should materialise. During the 1956 Bradwell Inquiry, this concern was summed up in emotive headlines such as 'Dead Sea' and 'River of Death'. It is a matter of history now that such fears of wide-scale and profound alteration of marine ecosystems resulting from thermal discharges at Bradwell and elsewhere in Britain proved to be unfounded. Fortuitously, the commissioning of Bradwell in 1962-63 coincided with one of the coldest winters on record. The Blackwater froze over, with vast mortalities of organisms. One result of immediate significance was that oysters living near the cooling water outfall had avoided the almost complete mortality suffered elsewhere in the estuary [1]. Periodic surveys of the Blackwater undertaken by MAFF and CEGB since the commissioning of Bradwell have continued to show es- 
sentially the same community structure as that recorded prior to construction of the power station [2].

The question of the impact of thermal discharges on commercial oyster populations continues to attract debate. The Solent oyster fishery developed shortly after the commissioning in 1970 of Fawley Power Station, a 2000 MWe oil-fired plant which discharges warm water into the Solent. By the late 1970s it had become Europe's largest self-sustaining commercial fishery for $O$. edulis, with a peak annual yield in excess of 1000 tonnes [3]. It is clear that this fishery has flourished, despite its intimate exposure to the discharge and yet, when in 1988 the CEGB published proposals for the construction of an $1800 \mathrm{MWe}$ ' $B$ ' station on the same site, the oyster issue was again raised, this time by both local fishermen and regulators.

The position of the regulators was set by EEC Directive 79/923/EEC on 'The Quality Required of Shellfish Waters'. Areas inclusive of the existing and proposed thermal discharge had been designated EEC Shellfish Waters and were subject to a maximum recommended temperature rise of $2{ }^{\circ} \mathrm{C}$ above ambient. The fishermen raised several new objections, including the possibility that thermal stress might increase susceptibility to Bonamia infection. Bonamia is a protozoan parasite which has reached epidemic levels and wiped out populations in European and some English South coast fisheries. A study commissioned by CEGB into stress in oysters demonstrated that thermal shock could induce stress but it was never demonstrated that this would increase Bonamia susceptibility. Other work [4] has demonstrated that temperature rises typical of power stations operating in British coastal waters would push oysters towards, rather than beyond, their optimum growth temperatures. The plans for Fawley ' $\mathrm{B}$ ' were eventually withdrawn and these issues were never fully resolved.

Thermal discharge effects on other marine benthos were investigated in an intensive three year study at Kingsnorth Power Station, Kent [5]. This station is well suited to the investigation of thermal effects, since the outfall discharges into the head of a canal/creek system and exhibits clearly defined temperature gradients, thermal fronts and cyclical temperature fluctuations. Animal communities were investigated over a $4 \mathrm{~km}$ reach of the creek; the temperature rise at the head was around $10^{\circ} \mathrm{C}$ and at the lowest (reference) site $3^{\circ} \mathrm{C}$. The main effect was a $40 \%$ reduction in the number of species in the upper part of the creek compared with the reference site. This was accounted for by the absence of stenothermal species (e.g. the molluscs Petricola pholadiformis and Cerastoderma edule). Intertidal species (e.g. the annelids Tubificoides amplivasatus and Cauleriella zetlandica) being tolerant of thermal shock, spread opportunistically into subtidal areas to produce very dense populations. Langford [6] noted a similar reduction in fish species diversity in the upper part of the creek but with very large numbers of warm- 
water species such as sea bass ( $D i$ centrarchus labrax) and grey mullet (Liza auratus). The main conclusion that can be drawn from these studies is that, whilst increased temperatures may reduce species diversity, effects are local and restricted essentially to the area of direct impingement of the warm water plume onto the sea bed.

The effects referred to so far are all 'near-field', i.e. occurring within the mixing zone of the thermal discharge. Of increasing interest are the 'far-field' effects, that is the elevation of water temperature by perhaps only a fraction of a degree over a wide area. This concept is valid principally within a semi-enclosed body of water such as an estuary. For most species, the effect will be insignificant compared with natural temperature fluctuations. Organisms most likely to be affected are those living at the northern (warmwater species) or southern (cold water species) limits of their distribution. Whilst there are no definitive data, the potential for this effect can be inferred from reports of 'warm-water' fishes of Mediterranean origin (e.g. sea bass and red mullet Mullus surmeletus) penetrating further north into British waters during warm years. After a series of increasingly warm winters from 1986 to 1990 exceptionally high recruitment was observed in a number of such species in the Bristol Channel [7]. It is also well established that successful sea bass recruitment is in part dependent upon warm winters (Henderson and Holmes, pers. comm.) and a recognised fact that young bass congregate in the warm waters around power station outfalls [8]. It is interesting to speculate on the effects of decommissioning power stations in bass nursery areas, or indeed of lowering the water temperature by the addition of chilled water arising from, for example, gasification plant.

\section{CONTROL OF BIOFOULING}

Whilst the Bradwell Inquiry was considering the possible effects of a power station on oysters, mussels (Mytilus edulis) were crippling stations from Camarthen to Blyth. Between 1957 and 1964, Marchwood Power Station (Hampshire) alone suffered 4000 condenser tube failures from mussels. The problems arose from mussels settling and growing on hard surfaces within the water intakes where they could take advantage of the supply of plankton from the incoming water. If dislodged they could become wedged in condenser tubes causing blockages or, at worst, perforation, leading to boiler feed water contamination, boiler corrosion and turbine blade damage. At Poole, 300 tonnes of mussels and barnacles were removed during one annual overhaul.

Although chlorine was being used at these stations, application was intermittent. At one station, continuous, low level chlorination was tried and proved to be successful. Further experimental work by biologists at Poole Power Station showed that the lowlevel technique prevented mussel settlement, reduced growth in mus- 
sels which had already settled, and controlled microfouling (slimes) on heat exchangers. Today, low-level chlorination is still the preferred option at most coastal power stations.

Environmental concern over the discharge of residual chlorine has prompted constant review of alternative methods but, to date, no better alternative has been found. Current research at Fawley is aimed at reducing the amount of chlorine required, thereby reducing discharges. In practise, very little free chlorine persists beyond the point of discharge, on account of chemical reactions taking place within the cooling system and discharge zone. Typically, and initial dose yielding $0.2 \mathrm{mg} \mathrm{Cl} \mathrm{I}^{-1}$ at the condenser inlet will have decayed to around $0.1 \mathrm{mg} \mathrm{Cl} \mathrm{I}^{-1}$ at the point of discharge, and by a further factor of ten within $1000 \mathrm{~m}$ along the plume axis [9].

No adverse effects have been identified in Britain as a result of such discharges, though for non-target organisms (plankton), exposure to the higher chlorine levels within the cooling system represents a risk additional to the physical hazards of transit [10]. The consequences for the majority of planktonic species are negligible since the nutrients released at death are quickly reassimilated by the ecosystem. The risk of high mortalities amongst the eggs or larvae of commercial fish and shellfish has led to lengthy studies to ensure that water intakes are placed well away from spawning grounds of such species [11].

\section{EFFECTS OF WATER ABSTRACTION ON FISHERIES}

The capture of predominantly small fish on CW intake screens is one of the more evident environmental effects of power generation and has been a recurring source of contention, especially with commercial fishermen. It is acknowledged that this is an additional cause of mortality, like the wastage of discarded undersized fish in the fishing industry, which should be put into its proper context.

A programme of CW screen sampling has been carried out over many years at different power station sites. The surveys are statistically designed to overcome sampling bias caused by tidal and seasonal influences. At Hinkley Point 'B' Power Station, monthly sampling has been maintained now for eleven years. Though not all coastal power stations have been sampled over this length of time, information has been gathered from enough sites representative of different marine habitats and intake designs to develop models which can be used to predict fish catch at other sites and even for 'green field' sites. The PISCES expert system developed at Fawley allows the non-expent to predict at-risk fish communities, and catch rates at proposed water intakes, for any point around the British coast. Such tools are valuable aids to environmental impact assessment.

The first attempt to place fish catches by power stations into the context of stock sizes and commercial landings was made for Sizewell ' $A$ ' 
Power Station in 1983 [12]. Local fishermen were objecting to the proposal to build Sizewell 'B', on the grounds that the catch of undersized fish would be increased substantially with two stations operating. It was shown that the catches by the ' $A$ ' and ' $B$ ' stations would amount to only a small fraction of the commercial catch (Table 1), equivalent to the catch of a single small trawler, and would be indistinguishable amongst natural fluctuations. Similar findings have been reported [13] for estuarine power stations, where catches of juveniles could be expected to be higher due to the presence of fish nursery areas. The long time series of catch data collected from Hinkley Point provide a direct demonstration that sustained cropping by several power stations in the Severn Estuary and Bristol Channel has not led to any sustained depression of fish or shrimp numbers [14].

Population studies hold the key to understanding the nature of impacts upon fish and shrimp populations. The central idea is to establish the size of the population from which the animals are cropped. This is straightforward for major commercial stocks for which estimates are made regularly under the auspices of the International Council for the Exploration of the Sea (ICES) (see Table 1) but for many species such data are not routinely available.

At Fawley Power Station, recorded captures of the sand smelt (Atherina boyeri), a small inshore fish, were of the order $10^{5}$ individuals per year. The population structure over the first ten years operating life of the station showed no significant alteration by this sustained level of cropping [15]. Such findings indicate a high degree of natural resilience in inshore fish populations.

In a study of the brown shrimp (Crangon crangon), morphometric characteristics were used to distinguish population boundaries of shrimps taken from different coastal

Table 1. - Comparison of fish loss due to Sizewell ' $A$ ' Power Station with loss due to commercial fishing vessels, as \% of North Sea stock (Year: 1983) [12].

\begin{tabular}{lccc}
\multicolumn{1}{c}{ Species } & $\begin{array}{c}\text { ICES Stock Size } \\
\text { (millions) }\end{array}$ & $\begin{array}{c}\text { Power Station } \\
\%\end{array}$ & $\begin{array}{c}\text { Commercial } \\
\%\end{array}$ \\
Plaice & 685 & 0.00072 & 17 \\
Sole & 210 & 0.013 & 23 \\
Dab & 4900 & 0.00034 & $?$ \\
Whithing & 3500 & 0.0087 & 47 \\
Cod & 845 & 0.00044 & 53 \\
Herring & 7460 & 0.0017 & 15 \\
\hline
\end{tabular}


localities [16]. The purpose of this study was to establish whether catches of up to 10 tonnes per annum at power stations such as Hinkley Point and Sizewell were of any significance to stocks. It was demonstrated that there are six major populations of shrimps around the coast of England and Wales. These already support fisheries that are large in relation to power station catches. Any impact would be minor, being spread out over a population as a whole.

Some benefits arise from the capture of organisms on intake screens. It was recognised back in the 1960 s that power station and other industrial water intake screens offer the opportunity for low-cost monitoring of fish and other natant organisms. Power stations on the Thames Estuary provided evidence for the recovery of fish populations following pollution abatement, and this monitoring has continued to this day at West Thurrock Power Station by the National Rivers Authority. Regular annual sampling from the screens of Kingsnorth and Oldbury Power Stations has enabled MAFF scientists to monitor changes in year class strength in sea bass [8]. The 11-year sampling programme at Hinkley Point has provided a wealth of data on the estuarine community which are being used to develop more generalised models of estuarine community dynamics. Such models help us to understand how a wide variety of anthropogenic impacts, ranging from commercial fishing to tidal power generation, might affect estuarine communities.

\section{SOLID WASTE DISPOSAL AND UTILISATION}

The power industry has always had a major solid waste disposal requirement arising from coal ash production. From 1994, this burden will be increased by the commissioning of flue gas desulphurisation (FGD) plants using the limestone-gypsum process. For a $1800 \mathrm{MWe}$ coal fired power station using this FGD process, there will be an annual production of $10^{6}$ tonnes of pulverised fuel ash (PFA) and $0.5 \times$ $10^{6}$ tonnes of gypsum. The majority of this material, as in the past, will be sold to the constructioin industry or used for land reclamation and landfill. Sea dumping has never been a major route for disposal. A PFA disposal site located off the Northumbrian coast has received a part of the PFA production from Stella and Blyth power stations since the 1950s. The ecological consequences of this practise have been shown to be minimal [17], limited essentially to a blanketing of marine benthos over the immediate area of deposition. Despite this, marine disposal will cease by 1993.

Following successful reports from the Coal Waste Artificial Reef Programme (C-WARP) in the USA [18], the CEGB in 1986 began to consider the use of consolidated blocks of PFA and gypsum materials for habitat enhancement, and in 1988 commissioned Southampton University to undertake the Poole Bay Artifical Reef Project. The aim of this project is to investigate the properties of blocks of different composition and their poten- 
tial for reef construction. Results from the first exposure season of the reef indicate no loss of structural integrity, an abundant and diverse fauna and flora and negligible transfer of toxic metals from the bocks to the epibiota [19]. Public interest in reef construction for leisure uses (sport angling and diving) and for mariculture is growing. The future of reefs made from these materials will depend on economic factors and licensing success.

\section{ENVIRONMENTAL ASSESSMENT}

\section{European Council Directive} 85/337/EEC requires the power industry to prepare environmental statements for all major new developments. The long tradition of research into the environmental consequences of power generation has placed the industry at the front of environmental assessment developments in Britain [20]. Continuing research will maintain this position and ensure that the best principles of environmental responsibility are upheld.

\section{REFERENCES}

[1] Crisp D.J. The effects of the severe winter of 1962-63 on marine life in Britain. J. Anim. Ecol., 33, 1965, pp. 165-210.

[2] Hawes F.B., Coughlan J. and Spencer J.F. Environmental effects of the heated discharge from Bradwell Nuclear Power Station, and of the cooling systems of other stations. In
Environmental Effects of Cooling Systems at Nuclear Power Plants, International Atomic Energy Agency, Vienna, 1975, pp. 423-448.

[3] Key D. and Davidson P.E. A review of the development of the Solent oyster fishery, 1972-80. Laboratory Leaflet No. 52, MAFF Direct. Fish. Res., Lowestoft, 1981, 36 pp.

[4] Buxton C.D., Newell R.C. and Fields J.G. Response surface analysis of the combined effects of exposure and acclimation temperatures on filtration, oxygen consumption and scope for growth in the oyster Ostrea edulis. Mar. Ecol. Prog. Ser., 6, (1), 1981, pp. 73-82.

[5] Bamber R.N. and Spencer, J.F. The benthos of a coastal power station discharge canal. J. mar. biol. Ass. U.K., 64, 1984, pp. 603-623.

[6] Langford T.E. The effects of a thermal discharge on the growth and feeding of bass, Dicentrarchus labrax (Linnaeus, 1758) in the Medway Estuary, England. Central Electricity Generating Board, Publ. No. TPRD/L/3126/R87, 1987, 50 pp.

[7] Holmes R.H.A. and Henderson, P.A. High fish recruitment in the Severn Estuary: the effect of a warm year? J. Fish Biol., 1990, 36, pp. 961-963.

[8] Pawson M.G. and Pickett G.D. The bass (Dicentrarchus labrax) and management of its fishery in England and Wales. Laboratory Leaflet No. 59, MAFF Direct. Fish. Res., Lowestoft, 1987, $37 \mathrm{pp}$.

[9] Coughlan J. and Davis M.H. Concentrations of chlorine around marine cooling water outfalls: validation of a model. In Water Chlorination: Environmental Impact and Health Effects, Vol. 5, eds. Jolley, R.L., Bull, R.J, Davis, W.P., Katz, S., Roberts, M.H., Jr. and Jacobs, V.A., Ann Arbor, MI: Ann Arbor Science Publishers Inc., 1985, pp. 1459-1468.

[10] Coughlan J. and Davis M.H. Effect of chlorination on entrained plankton 
at several United Kingdom coastal power stations. In: Water Chlorination: Environmental Impact and Health Effects, Vol. 4, Book 2, eds. Jolley, R.L., Brungs, W.A., Cotruvo, J.A., Cummings, R.B., Mattice, J.S. and Jacobs, V.A., Ann Arbor, Ml: Ann Arbor Science Publishers Inc., 1983, pp. 1053-1063.

[11] Henderson P.A. The vertical and transverse distribution of lanal herring in the River Blackwater estuary, Essex. J. Fish Biol., 31, 1987, pp. 281-290.

[12] Turnpenny A.W.H., Utting N.J., Millner R.S. and Riley J.D., The effect of fish impingement at Sizewell A Power Station, Suffolk, on North Sea fish stocks. Central Electricity Generating Board, Pub. No. TPRD/L3270/R88, 1988, 40 pp.

[13] Turnpenny A.W.H. Fish impingement at estuarine power stations and its significance to commercial fishing. $J$. Fish Biol., 33 (Supplement A), 1988, pp. 103-110.

[14] Henderson P.A. and Holmes R.H.A. On the population dynamics of dab, sole and flounder within Bridgwater Bay in the lower Severn Estuary, England. Neth. J. Sea Res., (in press), 1991.
[15] Henderson P.A., Turnpenny A.W.H. and Bamber R.N. Long-term stability of a sand-smelt population subject to power station cropping. J. Appl. Ecol., 21, 1984, pp. 1-10.

[16] Henderson P.A., Seaby R. and Marsh S.J. The population zoogeography of the common shrimp (Crangon crangon) in British waters. Central Electricity Generating Board, Pub. No., ESTD/L/0009/R89, 1989, 16pp.

[17] Bamber R.N. Potential environmental effects of dumped pulverized fuel ash in the sea. Central Electricity Generating Board, Pub. No. RD/L/3471/R89, 1989, 7Ppp.

[18] Woodhead P.M.J., Parker J.H. and Duedall I.W. The use of by-products from coal combustion for artificial reef construction. In Artificial Reefs - Marine and Freshwater Applications, ed. D'Itri, F.M., Lewis Publications, Chelsea, Michigan, USA, 1986, pp. 265-292.

[19] Collins K.J., Jensen A.C. and Lockwood A.P.M., Fishery enhancement reef building exercise. Chem. Ecol., 4, 1990, pp. 179-187.

[20] Bamber R.N. Environmental impact assessment: the example of marine biology and the UK power industry. Mar. Poll. Bull., 21, (6), 1990, 270274. 